\title{
Architecture MPS
}

\section{The View from the Blimp - Urban Image and the Telegenic Iconography of Sports Venues}

Paul Walker Clarke ${ }^{1}$

How to cite: Clarke, P. W. 'The View from the Blimp - Urban Image and the Telegenic Iconography of Sports Venues.' Architecture_MPS, 2015, 8(1): 2. DOI: https://doi.org/10.14324/111.444.amps.2015v8i2.000.

Published: 01 December 2015

\section{Peer Review:}

This article has been peer reviewed through the journal's standard double blind peer-review, where both the reviewers and authors are anonymised during review.

\section{Copyright:}

(C) 2015, The Author(s). This is an Open Access article distributed under the terms of the Creative Commons Attribution License (CC-BY) 3.0 https://creativecommons.org/licenses/by/3.0/, which permits unrestricted use, distribution and reproduction in any medium, provided the original author and source are credited • DOI: https://doi.org/10.14324/111.444.amps.2015v8i2.000.

\section{Open Access:}

Architecture_MPS is a peer-reviewed open access journal. 


\section{Title: Citying in the Anthropocene}

\section{Authors: Michael Jemtrud and Keith Ragsdale}

Architecture_media_politics_society. voll.8, no.2.

December 2015

Affiliation: McGill University School of Architecture

\section{Abstract:}

Historically, cities have been the repository and medium for our collective works, aspirations, and celebrations, driven by the promise of prosperity, wellbeing, and societal accord. Contemporary cities are technologically mediated in a manner that is reconfiguring the spatial and temporal conditions of the urban realm at an unprecedented scale and pace. We are experiencing a substantial transmutation of the material, utilitarian, everyday, spectacular, and symbolic reality of the urban, and with it, our capacity to be urbane, together. Although the design, construction, and operation of cities is seen as chiefly a practical and technical challenge, the "how" must be guided by questions of a fundamental, axiological nature - that is to say, questions concerning the values, ethics, qualities, political and aesthetic experience of urban life.

Such qualitative values are most potently expressed in the artefacts and events of a meaningful and productive cultural life. Understanding the relationship between variously formal and informal modes of urban collectivity - referred to in this paper as citying - and the formal practices of citymaking as a sophisticated cultural and technical enterprise motivates this inquiry. Furthermore, it will be argued here that such questions concerning culturally defined notions of values are inseparable from our ever-present awareness of humanity's role in whole-scale environmental degradation otherwise known as the era of the Anthropocene. Thus, a triad is formed - culturetechnology-environment - that fundamentally defines the way in which we make and inhabit contemporary cities. 


\title{
Title: Citying in the Anthropocene
}

\author{
Authors: Michael Jemtrud and Keith Ragsdale
}

Architecture_media_politics_society. vol.8, no. 2 .

December 2015

\section{Introduction: The Mediated City/City as Mediator}

Historically, cities have been the repository and medium for our collective works, aspirations, and celebrations, driven by the promise of prosperity, wellbeing, and societal accord. The late twentieth century heralded an epochal shift toward a world integrally reshaped by digital and communication technologies. Contemporary cities are technologically mediated in a manner that is reconfiguring the spatial and temporal conditions of the urban realm at an unprecedented scale and pace. We are experiencing a substantial transmutation of the material, utilitarian, everyday, spectacular, and symbolic reality of the urban, and with it, our capacity to be urbane, together. It is more accurate to say that we are actively making a new reality, as even habitual use of said technologies is an active and productive engagement that in turn transforms the social, cultural, political, ecological, and economic milieu. Given this context, questions arise concerning the relation between urban media in the twenty-first-century city and the socio-cultural construction of the public sphere. ${ }^{1}$ The following discussion seeks to configure a theoretical framework with nuanced categories and concepts that address these questions.

Although the design, construction, and operation of cities is seen as chiefly a practical and technical challenge, the "how" must be guided by questions of a fundamental, axiological nature - that is to say, questions concerning the values, ethics, qualities, political and aesthetic experience of urban life. Such qualitative values are most potently expressed in the artefacts and events of a meaningful and productive cultural life. Understanding the relationship between variously formal and informal modes of urban collectivity - here referred to as citying - and the formal practices of city-making as a sophisticated cultural and technical enterprise motivates this inquiry. Furthermore, it will be argued below that such questions concerning culturally defined notions of values are inseparable from our ever-present awareness of humanity's role in whole-scale environmental degradation otherwise known as the era of the Anthropocene. Thus, a triad is formed - culture-technology-environment - that fundamentally defines the way in which we make and inhabit contemporary cities. 


\section{Amps}

What gives the city the capacity to be an active agent and medium for the coexistence of people and things is not its efficient or optimized operation but rather, first and foremost, a function of its role as a grand cultural undertaking par excellence. The city is and always has been a technology of communication, transport, and commerce, but it is equally so a space for cultural memory, for gathering, and for civic participation, discourse, and performance. ${ }^{2}$ Urban centers act as a device for knowledge production and storage that "forms the masses" in geographically and culturally distinct ways. It is through this mediating function that cities harbor and actively participate in the production of divergent and shared values and aspirations of a heterogeneous mass of people and things.

Cities demand our attention but similarly allow for distracted states of individualized, habitual peregrination and use. At times cities exude and nurture a legible shared purpose that binds within the cosmopolitan horizon of individual, parochial, and public concerns. Equally so, cities are in a constant mode of refiguration, existing in a perpetual virtual state where latencies emerge and are capitalized upon by various interlocutors, from developers and architects to citizen groups, municipal officials, the homeless, and hurricanes. Cities and the public realm need constant attention, yet as the most mobile and connected people in history, it is generally claimed that we are the most distracted culture. The supposition goes that this is a consequence of ubiquitous computing and unrestricted access to a superabundance of information that places inordinate, constant, and competing demands on our attention.

The proliferation and continual insertion of urban media within the fabric of the city constitutes a powerful infrastructure that carries complex and largely unknown consequences for the public realm. As Bruno Latour states: "Technology, for its part, seeks to be hidden." 3 The oscillation between our habitual and intentional modes of distraction and attention operates within this veiled technological platform inclusive of a plethora of mediating devices and the informational sphere generated by those devices.

Undoubtedly, pervasive computational and electronic communication networks, the breadth and depth of information received, manipulated, and produced within personal and public realms, alter our relation to others and to the physical and cultural worlds. Streetscape imagery and lighting, soundscapes, way-finding mechanisms, and technologically enabled transportation systems use mobile apps, sounds, and imagery to orient and order users. They transform the surfaces, spaces, function, and temporality of the urban environments, affecting the manner in which we live, work, and play. Whether it be the devices constituting the "internet of things" or those installed in the name of the "smart city," a new form of connectivity and surveillance qualitatively divergent from the networks of streets, city centers, rail networks, and sewer systems has emerged. ${ }^{4}$ The array of sensors, cameras, Wi-Fi, mobile apps, multimedia, telepresence, and smartphone devices form an essential if largely invisible animate layer within the dense and polysemous urban palimpsest. As Mark Shepard states: 


\section{Amps}

Imbued with the capacity to remember, correlate and anticipate, this near future "sentient" city is envisioned as being capable of reflexively monitoring its environment and our behavior within it, becoming an active agent in the organization of everyday life in urban public space. ${ }^{5}$

Easy and continual access to information, data, and technologies create a paradoxical realm of experience, having the potential to simultaneously enhance and dull our attention to the environment and to others. It is in this context that the question of our capacity to be public and the nature of this realm is under scrutiny. City-making and living together is a practice that resides within a set of skills, tools, and techniques - what may be referred to as technics - that are in a state of fundamental transformation from their nineteenth-century legacy. To what extent is the future of the metropolis beholden to its past and determined by the contested technological, ecological, economic, social, and cultural regimes of the twenty-first century?

\section{City-Making and Citying}

To create, sustain, and enliven a city encompasses all dimensions - from the quotidian to the spectacular - of what it means to coexist as city-dwellers. City-making is an untidy, never-ending, mundane, and, at rare times, heroic work that humanity has performed for millennia. Strictly speaking, cities are not designed. As Brian Massumi asserts: "The designer is a helpmate to emergence." Conurbations come into being through a self-governing (autopoetic) mix of accident, planning, and design emerging through manifold given and hidden, intended and unintended forces. Regimes of power fuel the city-making endeavor as competing political, religious, economic, and environmental agendas vie to fashion this self-determining ontogenetic process of urbanity, and each regime does so after its own image.

The degree to which the fabric of the city frames and nurtures our capacity to be together is also a question of our ability to be attentive and our desire and capacity to be intimate with one another - meaning other people, but also buildings, buses, viruses, cats, dogs, trash, and carbon emissions. Intimacy is a key notion in considering cities and will be read through two primary registers below, the ecological and the economic, as articulated respectively by philosophers Timothy Morton and George Bataille.

First, however, a further distinction must be made between these two modalities of conceptualizing the urban realm, between city-making and citying. Both effectively reside in the realm of production, albeit in two different senses dictated by associated notions of what Bataille refers to as real and symbolic expenditure. The dynamic between these two modes of expenditure is epitomized within the realm of architecture and the city.

City-making is the consciously designed construction, management, and governance of cities. As Agamben states: "To understand what a metropolis is one needs to understand the process whereby power progressively takes 


\section{Amps}

on the character of government of things and the living, or if you like of an economy." It is dictated by the actual expenditure of resources, time, energy, and so on. City-making is explicitly technological as the continual reflection and mutual adjustment of the means-end relationship in the "endless process of using tools to produce and reproduce life." ${ }^{8}$ It exists primarily in the real and quantifiable realm of utility. In its most extreme form found in the rhetoric of the "smart city" and high-modern planning, city-making is an attempt to optimize and control the messiness of urban agglomeration and life.

Citying on the other hand is the critical-imaginative, albeit a largely tacit, unpredictable, and ordinary dynamic and exchange that actualizes the urban fabric. Citying has two overarching modalities, the everyday and the festal, the aesthetics for which take on both spatial and temporal dimensions - for example, "festal time" exists as a transgressive, celebratory mode of citying outside of the conditions of goal-oriented, everyday life. ${ }^{9}$ Like city-making, citying is a verb, a practice that must be practiced, requiring skills that are developed and honed over time. Its simultaneously enabling and prohibiting technics include a menagerie of devices such as building codes, by-laws, policy, social etiquette, media apps, codified signs and sounds, public space, and festivals. Everyday citying is a habitual co-creation between humans, things, and the environment. It is a cooperative endeavor, or better, an endeavor of cooperation that tends toward harmony, a collective and individual expression amongst strangers. This is not an idealized or romantic understanding of collectivity-as-community or consensus (or even a Kantian "good common world") but one that necessarily strives for the coexistence of all participants, living and non-living, within an agonistic political context. This necessity, however, is not simply nor primarily about techno-utilitarian notions of function, efficiency, survival, restraint, and conservation. Rather, as we will see below in Bataille's notion of the general economy, necessity is driven by a contrasting mode to create excess, expend, and transgress - collectively and intimately.

The query at hand is an effort to understand the relationship between city-making and citying as simultaneously contested and complementary endeavors within competing social, technical, and environmental regimes. The rapport between the design and governance of our cities, with that of the continual co-production of urban life, is not self-evident and arguably a continual contestation, inherently agonistic in nature. ${ }^{10}$ For instance, the discernible products of city-making from large infrastructure networks and public spaces to by-laws and norms that either allow for or prevent peaceful, festive, or defiant protest and gathering can either be complementary or counterproductive to citying. Examples of the complementary sort include simple bureaucratic accommodations like the free City of Chicago's "block party" permit, which allows for an easy and effective way to exercise our individual and collective skills to be together and expend at a parochial and public level. Yet, such apparatuses (when they exist) have complex and often hidden 


\section{Amps}

ideological foundations that are expressed under the guise of such notions as security, prosperity, sustainability, austerity, or the smart city.

If we assume that city-making and citying are symbiotic co-productions involving humans, things, and environmental relations, then this interdependence can further be read as a positive feature of intimacy and our capacity for being together. As mentioned, this is a practice requiring skills that must be exercised in order that the imagination and ability to be urbane does not become atrophied. As Richard Sennett has recognized:

De-skilling is occurring in the social realm in equal measure: people are losing the skills to deal with intractable differences as material inequality isolates them, short-term labour makes their social contacts superficial and activates anxiety about the Other. We are losing skills of cooperation needed to make a complex society work. ${ }^{11}$

The technics of collectivity is predicated on different levels and senses of intimacy and cooperation, yet in varying degrees - not all kinds of intimacy are desired or productive. Sometimes there is too much intimacy. For instance, Morton points out the strange and simultaneous expansion and collapse of massive spatial and temporal scales that now register - either by computation or in the wake of catastrophe - the consequences of two centuries of human industrial activity and consumption across the globe. Our understanding of planetary ecology and climate change figures into this reflection in a fundamental and irrevocable way.

\section{Intimacy in the Anthropocene}

The consideration of the city as a technological apparatus is inseparable from the predominant contemporary ecological paradigm in which questions concerning environmental stewardship dominate decision-making processes in the construction, use, and governance of cities today. The demonstrable and dramatic increase in extreme weather events and "natural" disasters have led to "resiliency" planning, institutes, and municipal departments in every major global city. We live with the dark, disconcerting awareness of our role in climate change that makes simple, phatic conversations about the weather impossible. ${ }^{12}$ There is no going back from baptizing the Anthropocene.

"Think about it," asks Morton, "a geological time (vast, almost unthinkable), juxtaposed in one word with very specific, immediate things -1784 , soot, 1945, Hiroshima, Nagasaki, plutonium. This is not only a historical age but also a geological one. Or better: we are no longer able to think history as exclusively human, for the very reason that we are in the Anthropocene."13 More pointedly, Morton identifies global warming as "the ecological trauma of our age, the very thing that defines the Anthropocene as such." 14 Carbon emissions and radioactive fallout, melting ice caps and rising sea levels, these are not merely environmental phenomena but environmental entities whose 


\section{Amps}

presence indicates "the logarithmic increase in the actions of humans as a geophysical force." ${ }^{15} \mathrm{We}$ are dealing with objects that are hyper because they are nonlocal and atemporal, which, as Morton observes, "confound the social and psychic instruments we use to measure them - even digital devices have trouble. Global warming requires tremendous computing power to model in a realistic way." 16 The reality of our ecological emergency is thus understood through the indexical register of information "that NASA, Google Earth, and global warming mapping open up," as Morton continues:

The more information we acquire in the greedy pursuit of seeing everything, the more our sense of a deep, rich, coherent world will appear unavailable: it will seem to have faded in the past (nostalgia) or to belong only to others (primitivism). Some of us will eventually think that we once inhabited this deep, rich, lost world. Others will realize that even this sense of loss is an illusion created by our current modes of seeing. ${ }^{17}$

The visualization of environmental data makes clear the enormity of our ecological crisis, but in turn, we also find that these forces operating at such an enormous spatial and temporal scale impinge upon us at a very intimate scale as well - in a way, too close for comfort. "The ecological thought spreads out in both time and space," writes Morton, "but thinking big doesn't contradict being intimate." 18 In this way Morton ultimately returns to questions concerning ethics and human subjectivity.

The imperative of coexistence stems from an acknowledgement and embrace of the radical intimacy shared amongst human and nonhuman entities alike, or in other words, "the simple fact that existence is coexistence." 19 It is rather this intimacy as a close-up and personal view of others - "a sense of being close, even too close, to other lifeforms, or having them under one's skin" 20 - that fosters the kind of ecological awareness that has arguably become socially and politically transformative through the modes of citymaking and citying. But although intimacy is the reality of ecological coexistence, this sense of radical proximity is not necessarily a catalyst for peaceful, non-violent living, and this is true in thinking ecology as well as economics and governance. As Morton observes: "Our intimacy with other beings is full of ambiguity and darkness. [...] If we edit out the ambiguity and darkness, we achieve nothing but aggression." ${ }^{21}$ This awareness of ecological intimacy makes evident our state of coexistence with beings, human and nonhuman, and gives rise to the imperative of ecological collectivity.

Collective intimacy in action, however, is not commensurate with homogeneous communal agreement or cohesion. Belonging is not intimacy. Collectives are in theory infinitely extensible as heterogeneous groupings. Collectivity is a technics of negotiating dark, ambiguous, contested realms and regimes. Morton inverts the common consideration that the imperative of sustainability must descend top-down from a greater sense of communal belonging. There is no umbrella term, no flag or banner under which the 


\section{Amps}

ecological thought marches, or as Morton puts it: "Collective intimacy can't be about feeling part of something bigger or losing yourself in an intoxicating aesthetic rush, but it can be a lot like falling in love, having the often scary but ultimately positive qualities of 'weakness, vulnerability, and incompletion."'22 In this way, Morton's intimacy also suggests a certain "quiescence" 23 or letting-go held in common by the collective, but moreover, the ethical aftereffect of intimacy becomes not only a letting-go but a giving to the other - an expenditure without return.

\section{Intimacy and the Two Spheres of Expenditure}

Georges Bataille has rethought economy in terms of the dialectic between what has been termed the restrictive and the general economies. Although the discussion of these ideas centers upon Bataille's The Accursed Share, first appearing in 1967, it is best to begin with his much earlier essay on "The Notion of Expenditure" published in 1933. The essay is a criticism of the principles of classical utility, or the relation of material utility and pleasure. "On the one hand, this material utility is limited to acquisition (in practice, to production) and to the conservation of goods; on the other," continues Bataille, "it is limited to reproduction and to the conservation of human life (to which is added, it is true, the struggle against pain, whose importance itself suffices to indicate the negative character of the pleasure principle instituted, in theory, as the basis of utility)." ${ }^{24}$ Furthermore, productive activity (work, means-to-end) stands opposed to unproductive activity, thus for Bataille,

it is necessary to reserve the use of the word expenditure for the designation of these unproductive forms, and not for the designation of all the modes of consumption that serve as a means to the end of production. Even though it is always possible to set the various forms of expenditure in opposition to each other, they constitute a group characterized by the fact that in each case the accent is placed on a loss that must be as great as possible in order for that activity to take on its true meaning. ${ }^{25}$

As such, "unconditional expenditure, no matter how contrary it might be to the economic principle of balanced accounts (expenditure regularly compensated for by acquisition)," has a direct corollary to the "principle of loss." 26 Expenditure (without return) is opposed to consumption; it entails loss and may be understood as a giving away freely without expectation of recompense. Consumption along these lines is based on labor and return, as in the production of commodities and their consumption.

We will find then in Bataille's The Accursed Share that modes of consumption (calculated return and profit) is the domain of the restrictive economy, also referred to as the sphere of utility. The general economy, in contrast, is that of biological systems, as Bataille observes, it is a system "determined by the play of energy on the surface of the globe," always an excess energy, and 


\section{Amps}

"if the excess cannot be completely absorbed in its growth, it must necessarily be lost without profit; it must be spent, willingly or not, gloriously or catastrophically." 27 By reconsidering Bataille's economic model as two spheres of expenditure, Richard Lee suggests that "the sphere of utility itself presupposes an entire sphere of expenditure without return that makes possible the sphere of utility in which energy is used for productive purposes. Without the sphere of glorious exuberance, utility itself will come to be destructive - un-useful." 28 In considering parallels between Martin Heidegger's distinction of ready-tohand and present-at-hand and Bataille's restrictive and general economy, "it becomes clear that some entities must be placed outside the sphere of utility," as Lee writes: "It is utility that makes an entity a thing, but it is glorious exuberance that removes entities from the universe of 'things' and returns them to another sphere." ${ }^{29}$ In another sense, what Lee calls "the sphere of glorious exuberance" might also be considered the sphere of collective intimacy.

For Bataille, intimacy refers to a sacred state of being - also where sacred things are made - that has been displaced by the profane sphere of utility. Intimacy, therefore, resides beyond the sphere of utility, outside of the restricted economy and beyond to where true self-less collectivity arises as cultural co-production, the general economy of "being-in-common." 30 Bataille makes a parallel connection between real and symbolic expenditures explicit in reference to artistic and architectural productions:

From the point of view of expenditure, artistic productions must be divided into two main categories, the first constituted by architectural construction, music, and dance. This category is comprised of real expenditures. Nevertheless, sculpture and painting, not to mention the use of sites for ceremonies and spectacles, introduces into architecture the principle of the second category, that of symbolic expenditure. For their part, music and dance can easily be charged with external significations. ${ }^{31}$

The model of Bataille's socio-economic theory sets up an opposition between the objective (real, rational, restrictive) material world and the subjective (symbolic, irrational, general) world of intimacy, which for Bataille, however, "is never separated from external elements, without which it could not be signified." 32 As such, there is an "indirect" or "vicarious" relation between real and symbolic expenditures, between a thing as cultural co-production and its expression of collective intimacy. ${ }^{33}$

Later in writing The Accursed Share, Bataille rehabilitates the term "consumption" as a productive force, an "intimate feeling" elsewhere described as a burning up. For Bataille, "intimate feeling is a consumption, it is consumption that expresses [intimacy], not a thing, which is its negation." ${ }^{34}$ As such, Bataillean intimacy finds its expression in symbolic, cultural expenditure, in shared cultural activities separate from the restrictive economy of work and calculated returns, and it is this intimacy that links the individual to the collective. Blurring the boundaries between the restrictive and general 


\section{Amps}

economies, the threshold between the sphere of material utility and the sphere of collective intimacy becomes less distinct; they begin to interpenetrate, and the alchemical combustion of real and symbolic expenditures begins to conjure surprising aesthetic and ethical dimensions.

\section{Conclusion: Citying as Cultural Excess (Against Austerity)}

Limits are the condition of possibility for economies of excess and cultural expenditure. We are in an era where the knowledge of limits is glaring and has prompted us to acknowledge our role in climate change, that is, the Anthropocene as such. Taken from the intersecting perspectives of cultural excess and collective intimacy as articulated above, an ethical inversion of the current logics of sustainability and resiliency becomes imperative. In other words, notions of sustainability must be embedded in endeavors of shared cultural expenditure, not austerity or mere conservation.

The implicate order of the city operates at a vast and often disconcerting range of temporal and spatial scales. The awareness of a given urban context increasingly exceeds the proportions of the local and immediate, or even historical. A fundamental assertion here, therefore, is that cultural manifestation and ecological thought are indissoluble one to the other in the era of globalization, consumption, tourism, global warming, information, and the so-called knowledge economy. Any consideration of collective formation and expenditure must consider the relation between excess and consumption relative to the predominant ecological milieu. Undoubtedly, socio-cultural wellbeing, economics, and environment are the primary forces determining the evolution and design of our cities. From initiatives such as "Cities of Culture" and "Cities of Design" to "2030 Districts" and a plethora of sustainable cities programs, the tension between desire, responsibility, excess, and limits is paramount. Whether it falls within the rubric of sustainability, resiliency or other variations of environmentalism, the leading character of ecological thinking is one of crisis, austerity, and the continual calculation of limits, whereas cultural expenditure is commonly seen within the realm of superfluous exuberance and excess. This paradoxical tension between culture and conservation plays out in such realms as policy and neoliberal capitalism or technological interventions of control like the so-called "Smart City" as well as in consumption directed advertising and district branding initiatives such as "Eco-quarters" and "Innovation Districts." Even large-scale tourism and festivals have the tendency to produce effects contradictory to their intentions, like displacing a city's permanent inhabitants.

The logic of mere survival embedded in notions of sustainability is diametrically opposed to collective societal exuberance. Whereas cultural production is an ecstatic, transgressive and excessive expenditure of energy, conservation of resources and austerity is one of continually defining limits and exercising restraint. A primary question in this line of inquiry concerns this seeming paradox between cultural expenditure and environmental stewardship as 


\section{Amps}

tacitly embodied or overtly expressed in urbanity, inclusive of festivals, protests, impromptu events, parkour, and other forms of mutual formation and urban performance.

Engagement with a festival, museum exhibition, urban event, or protest requires an enthusiastic and playful effort outside of one's habitual, or rather, purposeful work-life in an attentive and intimate manner. These occasions situated beyond mere utility or prosaic servitude entail - again evoking Bataille's expenditure without return - a "sacrifice" in the most affirmative sense of the term. ${ }^{35}$ Remembering that for Bataille, the word "expenditure" is reserved in the truest sense for unproductive forms of cultural and artistic productions in contrast to mere consumption as a means to the end of production; it is the intermingling of real and symbolic expenditure in the spaces, artefacts, and experiences - the architecture of the contemporary city - that gives citying and city-making its fullest expression.

Relatedly, Allan Stoekl's interpretation and extension of Bataille's theory of expenditure is relevant to thinking the economy and circulation of arts and ideas within the cultural sphere and its relation to environmental sustainability. Stoekl's reading suggests an inversion of survival as a means, not an end, wherein "expenditure [becomes] a limitless insubordinate act - a real end (that which does not lead outside itself)." ${ }^{36} \mathrm{He}$ endorses Bataille "in this primacy of the delirium of expenditure over the simple exigency of personal or even social survival. [. . .] This does not preclude, however, a kind of ethical aftereffect of Bataille's expenditure: survival for this reason can be read as the fundamentally unintentional consequence of expenditure, rather than its purpose." ${ }^{37}$ Stoekl finds in Bataille's economic theory an ecological one corresponding to excess and depletion, or the discovery of limits. "By viewing man as waster rather than conserver," following Stoekl's reading, "Bataille manages to invert the usual order of economics: the moral imperative, so to speak, is the furthering of a 'good' expenditure, which we might lose sight of if we stress an inevitably selfish model of conservation or utility." 38 Furthermore, Stoekl finds in the contrast between these two spheres of expenditure a choice between two alternatives, a choice that also entails an emergent ethical imperative. He writes:

The irony in all of this is that in the first [option], transgressive and "human" ethics will inevitably be sensitive to ecological questions - respectful of carrying capacity - through its very affirmation of waste. The second, attempting to limit severely or do away with waste and thereby affirm the particular interests of an individual or a closed social group, will only universalize the wasting the ultimate destruction - of the carrying capacity that serves as the basis of life. Conservation is therefore a logical aftereffect of expenditure; we conserve in order to expend. In other words, we conserve, not to perpetuate our small, monadic existences, but rather to make possible a larger generosity, a larger general economy that entails the transgression (in angoisse) of our narrow, selfish "practicality," our limitedness (i.e., the inevitable postponement of pleasure). ${ }^{39}$ 


\section{Amps}

Bataille's economic theory is therefore an ethical one that criticizes "the egodriven affirmation of utility," 40 and in turn, is positioned in opposition to the insidious brand of "hedonistic sustainability" that masks an apologetics of postindustrial consumer capitalism popular with corporations and celebrity architects today. ${ }^{41}$ This criticism is also shared by Morton, who writes: "The common name for managing and regulating flows is sustainability. But what exactly is being sustained? 'Sustainable capitalism' might be one of those contradictions in terms along the lines of "military intelligence."'42

The conditions of possibility for intimacy, intersubjectivity, publicity, and collectivity in the twenty-first-century mediated city have undoubtedly transformed. Machine-mediated intimacy is already a distanced form qualitatively other than that articulated in Bataille. In order to understand the consequences for citying and city-making it is essential to understand the relationship between normative and subversive modes of socio-cultural production and collectivity. Increasingly, these notions are technologically mediated in a manner and mode today qualitatively different than those of the past. But rather than reinforce predominant techno-environmental responses based on austerity, control, consumerism, and calculation of limits, the urban media platform of the twenty-first-century city holds the possibility to renew our sense of intimacy and revitalize the cultural realm.

The questions concerning the production of cultural value within the intersecting domains of city-making and citying may be reframed as follows. How can architecture, urban design, urban media, and such tools as policy facilitate a Bataillean glorious expenditure where arts and ideas circulate and gain currency within the general economy? Will these interventions also catalyze collectivity, where attentiveness to the other also entails a greater awareness of ecological limits and the planet's carrying capacity? Once more, Stoekl reminds us that "the very notion of a 'general' economy means that individual, isolated interest is in principle left behind, and that instead, a larger perspective is embraced, one in which the individual's concerns and worries are no longer paramount. Replacing them are the larger energy flows of the subject, of society, and of the universe." ${ }^{33}$ Interventions of this sort must aspire to be more than vapid entertainments, mere modes of distraction. Architecture, now inseparable from urban media, has an urgent role in creating a powerful awareness of the often contradictory and concealed dilemma of the Anthropocene, but furthermore, architecture - the site and activity of intermingling real and symbolic realms of expenditure - also possesses the potential for enabling the technics of collectivity and collective intimacy requisite to overcome this dilemma. Amongst the manifold cultural and ecological challenges facing us today, to live in the mediated city, a generous consideration of the common good within an irretrievably heterogeneous world is not only necessary but also engenders modes of city-making and citying to be celebrated now and in the future to come, in spite of its ambiguity and darkness, with courage and unabashed optimism. 


\section{Amps}

\section{Notes}

1 According to Martijn de Waal, urban media is understood as a collective term "for media technologies that in one way or another influence the experience of a physical location." See his The City as Interface: How Digital Media are Changing the City (Rotterdam: nai10 Publishers, 2014), 8.

2 See Friedrich Kittler and Matthew Griffin, "The City is a Medium," New Literary History 27(4), Literature, Media, and the Law (1996): 717-29.

3 Bruno Latour, An Inquiry into Modes of Existence: An Anthropology of the Moderns (Cambridge, MA: Harvard University Press, 2013), 217.

4 These notions are discussed at length in Adam Greenfield, Against the Smart City (part 1 of The City is Here for You to Use) (Do projects; Kindle 1.3 edition, 2013); Malcolm McCullough, Ambient Commons: Attention in the Age of Embodied Information (Cambridge, MA: MIT Press, 2013); and Sherry Turkle, Alone Together: Why we Expect More from Technology and Less from Each Other (New York: Basic Books, 2012).

5 Mark Shephard, "Sentient City Survival Kit: Archeology of the Near Future" in Proceedings of the Digital Arts and Culture Conference, After Media: Embodiment and Context (Irvine, CA: University of California Press. 2009), 20.

6 Brian Massumi. "Technical Mentality Revisited: Brain Massumi on Gilbert Simondon," Parrhesia 7 (2009): 40.

7 Giorgio Agamben, "Metropolis" (March 10, 2007), trans. Arianna Bove, accessed August 10, 2014, http://www.egs.edu/faculty/giorgio-agamben/articles/metropolis.

8 Michael Weinstein, "Virtual Bataille," Parallax 7(1) (2010): 76.

9 See Donald Kunze. Art3Idea (2001), accessed April 28, 2015, http://art3idea.psu. edu/art3/mail/2.html.

10 See Chantal Mouffe, "Artistic Activism and Agonistic Spaces," Art \& Research: A Journal of Ideas, Contexts, and Methods 1(2) (2007), accessed December 3, 2009. http://www.artandresearch.org.uk/v1n2/pdfs/mouffe.pdf; and Agonistics: Thinking the World Politically (London: Verso Books, 2013).

11 Richard Sennett, Together: The Rituals, Pleasures, and Politics of Cooperation (New Haven, CT: Yale University Press, 2012), 8-9.

12 See Timothy Morton, The Ecological Thought (Cambridge, MA: Harvard University Press, 2010), and Hyperobjects: Philosophy and Ecology After the End of the World (Minneapolis, MN: University of Minnesota Press, 2013).

13 Morton, Hyperobjects, 5.

14 Ibid. 9.

15 Ibid. 7.

16 Ibid. 47.

17 Morton, The Ecological Thought, 56.

18 Ibid. 100.

19 Morton, Hyperobjects, 125.

20 Ibid. 139.

21 Ibid. 100.

22 Morton, The Ecological Thought, 126-7. 
23 Morton's term, see "Materialism Expanded and Remixed," accessed January 13, 2010, http://newmaterialismconference.blogspot.com/2010/01/materialismexpanded-and-remixed. html.

24 George Bataille, Visions of Excess: Selected Writings, 1927-1939, trans. Allan Stoekl (Minneapolis: University of Minnesota Press, 1985), 116.

25 Ibid. 118.

26 Ibid.

27 George Bataille, The Accursed Share: An Essay on General Economy, volume 2 (New York: Zone Books, 1991), 21.

28 Richard Lee, Jr. "Politics and the Thing: Excess as the Matter of Politics," in Reading Bataille Now, ed. Shannon Winnubst (Bloomington, IN: University of Indiana Press, 2007), 245.

29 Ibid. 246; italics in original.

30 Scott Cutler Shershow, The Work and the Gift (Chicago, IL: University of Chicago, 2005), 6-7, 223. Shershow's notion of "being-in-common" is informed by his reading of Jean-Luc Nancy's The Inoperative Community (Minneapolis, MN: University of Minnesota Press, 1991).

31 Bataille, Visions of Excess, 119-20; italics in the original.

32 Bataille, The Accursed Share, 129-30.

33 These are operative terms in Graham Harman's object-oriented philosophy; see his "On Vicarious Causation," in Collapse II: Speculative Realism, ed. Robin MacKay (Falmouth: Urbanomic, 2007), and The Quadruple Object (Winchester, UK, and Washington, DC: Zero Books, 2011). For Harman, there is no direct cause-effect relationship between two objects, that instead, relations (effects) are mediated vicariously by a third entity. This is an appropriate analogy for our purposes here, for example, how architectural objects mediate real and symbolic expenditures.

34 Bataille, The Accursed Share, 195; italics in the original.

35 Bataille, Visions of Excess, 116.

36 Allan Stoek1, "Excess and Depletion: Bataille's Surprisingly Ethical Model of Expenditure," in Reading Bataille Now, edited by Shannon Winnubst (Bloomington, IN: University of Indiana Press, 2007), 261; italics in the original.

37 Ibid.

38 Ibid. 253-4.

39 Ibid. 264-5; italics in the original.

40 Ibid.

41 In this case, we have in mind BIG and Heatherwick Studio's design for Google's new headquarters in Mountain View, California; for the phrase "hedonistic sustainability," see Bjarke Ingels, Yes is More: An Archicomic on Architectural Evolution (Cologne: Taschen, 2009), 50.

42 Morton, Hyperobjects, 111.

43 Stoekl, "Excess and Depletion," 266. 


\section{Amps}

\section{Bibliography}

Agamben, Giorgio. "Metropolis" (March 17, 2007). Translated by Arianna Bove. Accessed August 10, 2014. http://www.egs.edu/faculty/giorgio-agamben/articles/ metropolis.

Bataille, George. Visions of Excess: Selected Writings, 1927-1939. Translated by Allan Stoekl. Minneapolis, MN: University of Minnesota Press, 1985.

Bataille, George. The Accursed Share: An Essay on General Economy, volumes 2 and 3. New York: Zone Books, 1991.

Greenfield, Adam. Against the Smart City (part 1 of The City is Here for You to Use). Do projects; Kindle 1.3 edition, 2013.

Greenfield, Adam, and Mark Shepard. Urban Computing and Its Discontents. New York: Architectural League of New York, 2007.

Harman, Graham. "On Vicarious Causation." In Collapse II: Speculative Realism, edited by Robin MacKay. Falmouth: Urbanomic, 2007: 171-205.

Harman, Graham. The Quadruple Object. Winchester, UK, and Washington, DC: Zero Books, 2011.

Ingels, Bjarke. Yes is More: An Archicomic on Architectural Evolution. Cologne: Taschen, 2009.

Kittler, Friedrich, and Matthew Griffin, "The City is a Medium," in New Literary History 27(4), Literature, Media, and the Law (1996): 717-29.

Kunze, Donald. Art3Idea (2001). Accessed April 28, 2015. http://art3idea.psu.edu/ art3/mail/2.html.

Latour, Bruno. An Inquiry into Modes of Existence: An Anthropology of the Moderns. Cambridge, MA: Harvard University Press, 2013.

Lee, Jr., Richard. "Politics and the Thing: Excess as the Matter of Politics." In Reading Bataille Now, edited by Shannon Winnubst, 245-6. Bloomington, IN: University of Indiana Press, 2007: 240-51.

McCullough, Malcolm. Ambient Commons: Attention in the Age of Embodied Information. Cambridge, MA: MIT Press, 2013.

Massumi, Brian. "Technical Mentality Revisited: Brain Massumi on Gilbert Simondon.” Parrhesia 7 (2009): 36-45.

Morton, Timothy. The Ecological Thought. Cambridge, MA: Harvard University Press, 2010.

Morton, Timothy. "Materialism Expanded and Remixed.” Accessed January 13, 2010. http://newmaterialismconference.blogspot.com/2010/01/materialism-expandedand-remixed.html.

Morton, Timothy. Hyperobjects: Philosophy and Ecology After the End of the World. Minneapolis, MN: University of Minnesota Press, 2013.

Mouffe, Chantal. "Artistic Activism and Agonistic Spaces." Art and Research: A Journal of Ideas, Contexts, and Methods 1(2) (2007). Accessed December 3, 2009. http://www.artandresearch.org.uk/v1n2/pdfs/mouffe.pdf.

Mouffe, Chantal. Agonistics: Thinking the World Politically. London: Verso Books, 2013. 


\section{Amps}

Nancy, Jean-Luc. The Inoperative Community. Minneapolis, MN: University of Minnesota Press, 1991.

Sennett, Richard. Together: The Rituals, Pleasures, and Politics of Cooperation. New Haven, CT: Yale University Press, 2012.

Shephard, Mark. "Sentient City Survival Kit: Archeology of the Near Future." In Proceedings of the Digital Arts and Culture Conference, After Media: Embodiment and Context. Irvine, CA: University of California Press, 2009.

Shershow, Scott Cutler. The Work and the Gift. Chicago, IL: University of Chicago, 2005.

Stoekl, Allan. "Excess and Depletion: Bataille's Surprisingly Ethical Model of Expenditure." In Reading Bataille Now, edited by Shannon Winnubst. Bloomington, IN: University of Indiana Press, 2007: 252-82.

Turkle, Sherry. Alone Together: Why we Expect More from Technology and Less from Each Other. New York: Basic Books, 2012.

de Waal, Martijn. The City as Interface: How Digital Media are Changing the City. Rotterdam: nai10 Publishers, 2014.

Weinstein, Michael. "Virtual Bataille." Parallax 7(1) (2010): 76-80. 